\title{
Immunological Properties of Monoclonal Antibodies Specific for Meningococcal Polysaccharides: the Protective Capacity of IgM Antibodies Specific for Polysaccharide Group B
}

\author{
By CARLOS MORENO, ${ }^{1 *}$ JANE HEWITT,${ }^{2} \dagger$ KAREN HASTINGS $^{1}$ AND \\ DAVID BROWN ${ }^{2}$ \\ ${ }^{1}$ Department of Experimental Immunobiology and ${ }^{2}$ Department of Bacteriology, \\ The Wellcome Research Laboratories, Beckenham, Kent, U.K.
}

(Received 18 November 1982; revised 14 February 1983)

\begin{abstract}
Two IgM monoclonal antibodies, MB32 and MB34 specific for meningococcal polysaccharide group $\mathrm{B}$ have been raised. Both were detectable by radioimmunoassay and agglutination, but only MB34 was effective in counter immunoelectrophoresis and complement fixation. MB34 was also far more potent than MB32 when tested for passive protection of mice infected with either Neisseria meningitidis group B or Escherichia coli K1. These data demonstrate that group B-specific antibodies do play a protective role in mice infected with these bacteria.
\end{abstract}

\section{INTRODUCTION}

Antibodies to the capsular polysaccharide are known to play a major protective role in human immunity to meningococci (Goldschneider et al., 1969; Gotschlich et al., 1978). However, the in vivo biological and protective properties of antibodies specific for group B meningococcal polysaccharide are not very well understood, due in part to the poor immunogenicity of this particular antigen (Kasper et al., 1973a; Wyle et al., 1972). Even though the existence of Bspecific antibodies with demonstrable bactericidal (Kasper et al., 1973a) and protective (Frasch et al., 1976) activity has been reported, their low titres make characterization difficult, particularly in the presence of antibodies with specificities other than group $\mathbf{B}$.

It was considered that monoclonal antibodies, specific for group B polysaccharide could help in clarifying some of these issues, and this report describes the preparation of such antibodies, their immunological characterization and ability to protect mice challenged with lethal doses of Neisseria meningitidis $\mathrm{B}$ and also Escherichia coli $\mathrm{K} 1$ whose colominic acid antigen is chemically and antigenically undistinguishable from group B (Bhattacharjee et al., 1975, Counts \& Turck 1977; Kasper et al., 1973b).

\section{METHODS}

Bacterial strains. Neisseria mengitidis strains CN7619, CN7622 (both group B) were obtained from Dr C. Frasch, Bureau of Biologics, Food and Drug Administration, Bethesda, Maryland 20014, U.S.A., and correspond to his designates B16B6 and M931, respectively. Neisseria meningitidis CN7783 (group B) was obtained from the Public Health Laboratory, Manchester, and is equivalent to their Branham M993 strain. Neisseria meningitidis CN7038 (group C) was obtained from Dr E. Gotschlich, The Rockefeller University, New York, U.S.A., and corresponds to his $\mathrm{C} 11$ strain. Escherichia coli CN6158 came from the American Type Culture Collection and corresponds to NCTC 9007. Neisseria meningitidis strains were freeze dried and recovered as required on either blood agar or Mueller Hinton agar (Oxoid). They were then grown overnight in Tryptone Soya broth (Oxoid). Formalinized suspensions were prepared by adding formalin to $0.5 \%(\mathrm{w} / \mathrm{v})$. After $24 \mathrm{~h}$ the cultures were spun down, washed and resuspended in phosphate-buffered saline, $\mathrm{pH} 7 \cdot 2$ [PBS containing $50 \%(\mathrm{v} / \mathrm{v})$ glycerol]. Suspensions prepared in

† Present address: Celltech Ltd, 250 Bath Road, Slough, Berks, U.K. 
this way, containing about $10^{11}$ organisms $\mathrm{ml}^{-1}$, were maintained at $-20^{\circ} \mathrm{C}$; under these conditions they were found to remain stable for at least 6 months.

Preparation of meningococcal polysaccharide grotu B. MPS(B) was prepared from strain CN7783 according to the procedure described by Gotschlich et al. (1972). Chemical analysis indicated $1.3 \%$ protein and $0 \cdot 8 \%$ nucleic acid contamination. Lipolysaccharide was estimated to be less than $0.25 \%$. Identification was confirmed by chemical analysis of $\mathrm{N}$-acetylneuraminic acid, sensitivity to neuraminidase and nuclear magnetic resonance. Immunological reactivity was estimated by counter immunoelectrophoresis with rabbit anti-B serum (Wellcome Diagnostics, Dartford). The content of MPS(B) in the sample was estimated to be at least $95 \%$.

Immunization procedure for obtaining monoclonal antibodies. Female $\mathrm{CBAT}^{6} \mathrm{~T}^{6}$ mice, 8 weeks old, were given $0.7 \mathrm{mg}$ Corynebacterium parvum (Coparvax, Wellcome) on day 0 for non-specific stimulation of the immune response and splenomegaly (Adlam \& Scott, 1972). This was followed by $10^{8} \mathrm{~N}$. meningitidis $\mathrm{B}$ (CN7783) given intravenously on days 4 and 11. Spleens from mice having the highest anti-B titre by solid-phase radioimmunoassay were pooled and used for fusion.

The procedure used for fusion followed the general method of (Kohler \& Milstein, 1975) using a procedure described previously (Coates et al., 1981). Supernatants of primary wells were screened for specific (anti-B) antibodies by solid-phase radioimmunoassay, positive wells were cloned by limiting dilution and finally grown as ascitic tumours in BALB/c $\times$ CBAT $^{6} \mathrm{~F} 1$ hybrid mice primed $3 \mathrm{~d}$ earlier with $0.5 \mathrm{ml}$ pristane (Aldrich). Ascitic supernatants were pooled and tested for activity either directly or after precipitation of the immunoglobulin at $18 \%(\mathrm{w} / \mathrm{v}) \mathrm{Na}_{2} \mathrm{SO}_{4}$, followed by dialysis and freeze drying. MB32 and MB34 were both IgM antibodies.

Immunological assays. Solid-phase radioimmunoassay was performed on round bottomed soft titration plates (Dynatech) pretreated with $100 \mu \mathrm{g}$ poly-L-lysine $\mathrm{ml}^{-1}$ (Sigma, mol. wt 50000) for $1 \mathrm{~h}$ followed by $10 \mu \mathrm{g}$ polysaccharide $\mathrm{ml}^{-1}$ and blocked with $3 \%(\mathrm{w} / \mathrm{v})$ bovine serum albumin (BSA). The sera were diluted in $3 \%$ BSA (twofold dilutions), plates were incubated with ${ }^{125}$ I-labelled, immunopurified rabbit anti-mouse immunoglobulin $\left(1-3 \times 10^{4}\right.$ c.p.m. per well; $7-8 \times 10^{6}$ c.p.m. $\left.\mu \mathrm{g}^{-1}\right)$ and counted. Plates were washed five times with PBS after every incubation. Antisera were diluted in $3 \%$ BSA/PBS.

Counter immunoelectrophoresis was performed as described previously (Lifely et al., 1981) using a range of antigen concentrations from $0 \cdot 1$ to $100 \mu \mathrm{g} \mathrm{ml}^{-1}$.

Complement fixation was done in microtitre plates (Linbro, flat bottomed microelisa). Serial twofold dilutions of monoclonal antibody $(25 \mu \mathrm{l})$ were mixed with a range of $0 \cdot 1$ to $100 \mu \mathrm{g}$ antigen $\mathrm{ml}^{-1}(25 \mu \mathrm{l})$ followed by 1.8 haemolytic units of baby rabbit serum as a source of complement $(50 \mu \mathrm{l})$. After incubation for $1 \mathrm{~h}$ at $37^{\circ} \mathrm{C}$, a $2 \%$ $(\mathrm{v} / \mathrm{v})$ suspension of $(50 \mu \mathrm{l})$ sheep red blood cells previously sensitized with rabbit anti-sheep red blood cell haemolysin (Wellcome) was added and reactions were incubated for a further $2 \mathrm{~h}$. Plates were centrifuged at $300 \mathrm{~g}$ for $15 \mathrm{~min}$ at an angle of $30^{\circ}$ and haemolysis read at $405 \mathrm{~nm}$ in a Titertek Multiskan.

Bacterial agglutination was performed on a slide with formalin-fixed and washed bacteria $\left(2 \times 10^{10} \mathrm{ml}^{-1}\right)$.

Mouse protection model. The method used was similar to the procedures described by Calver et al., (1976), Holbein (1980) and Holbein et al. (1979). CBAT ${ }^{6}$ female mice (8 weeks old) were injected intraperitoneally with $10 \mathrm{mg}$ iron dextran (Imferon, Fisons) followed within $30 \mathrm{~min}$ by an intraperitoneal injection of $32 \mathrm{LD}_{50}$ of $N$. meningitidis suspended in PBS. Mortality was recorded for a $3 \mathrm{~d}$ period. The $\mathrm{LD}_{50}$ for the different strains used were as follows: CN7619, 260 c.f.u.; CN7620, 380 c.f.u.; CN7038, 7.8 × 104 c.f.u.; CN6158, 5 c.f.u.

\section{RESULTS}

Two IgM monoclonal antibodies (MB32 and MB34) with specificity for meningococcal polysaccharide B were used in these studies. Their potency by solid-phase radioimmunoassay is illustrated in Fig. 1. The linear segment of the curve was used to obtain the titre for each monoclonal antibody by extrapolating to zero binding, and gave values of 250 and $100 \mathrm{ng}$ immunoglobulin $\mathrm{ml}^{-1}$ for MB32 and MB34, respectively. These titres are considerably lower than those obtained for other monoclonal antibodies specific for $\mathrm{A}$ and $\mathrm{C}$ meningococcal polysaccharides (data not shown). It is not clear whether this reflects differences in the assay system, poor avidity of anti-B monoclonals or other factors. Both monoclonals gave negative results when tested with meningococcal polysaccharides groups A and C, BSA and poly-L-lysine which served as controls for specificity.

Other immunological assays performed with MB32 and MB34 are listed in Table 1. MB34 gave positive results in all the assays, counter immunoelectrophoresis was positive with MPS(B) but was negative with other meningococcal polysaccharides (A and $\mathrm{C}$ ) and after treatment of MPS(B) with neuraminidase. MB32 reacted weakly in agglutination tests, was nonprecipitating by counter immunoelectrophoresis and did not fix complement. 


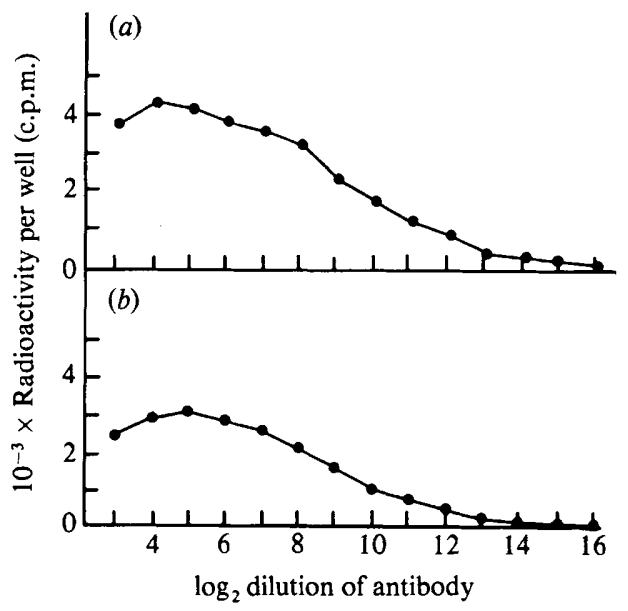

Fig. 1. Solid-phase radioimmunoassay performed with serial dilutions of MB34Al (a) and MB32A1 (b). The plate was coated with meningococcal polysaccharide B.

Table 1. Immunological assays performed with monoclonal antibodies specific for meningococcal group B polysaccharide

$\begin{array}{lcc}\quad \text { Assay } & \overbrace{\text { MB32 }}^{\text {Monoclonal antibody: }} & \text { MB34 } \\ \text { Radioimmunoassay } & + & + \\ \text { Counter immunoelectrophoresis } & -* & + \\ \text { Agglutination: } & & + \\ \text { N. meningitidis }(\mathrm{B}) & + & + \\ \text { E. coli } \text { K1 } & -+ & + \\ \text { Complement fixation } & +\end{array}$

* Negative at a concentration of $2.5 \mathrm{mg}$ immunoglobulin $\mathrm{ml}^{-1}$.

$\dagger$ Range tested: $500-0.5 \mu \mathrm{g}$ immunoglobulin $\mathrm{ml}^{-1}$.

The protective capacity of MB32 and MB34 was assayed in a mouse test (Fig. 2). This experiment indicated a clear passive protection bestowed by both MB32 and MB34 monoclonal antibodies, as seen in Fig. 2. From these results it was clear that the minimally protective dose of MB34 demonstrable when mice were challenged with $32 \mathrm{LD}_{50}$ of strain $\mathrm{CN} 7619$ was between 1 to $2 \times 10^{-5} \mathrm{mg}$ per mouse. In contrast, MB32 monoclonal antibody, although it was also an IgM antibody was about 500 times less potent and no further protection studies done with it are reported here. The protective effect was also demonstrable when MB34 monoclonal antibody was given $4 \mathrm{~h}$ after (Table 2) or $24 \mathrm{~h}$ before challenge (Table 3). In both cases, however, the protective capacity was clearly less than when antibody was given within $1 \mathrm{~h}$ of challenge. Since $E$. coli $\mathrm{K} 1$ polysaccharide antigen is very similar, if not identical, to MPS(B) (Bhattacharjee et $a l ., 1975)$, the capacity of MB34 to protect mice from lethal challenge with this organism was also explored (Table 4). Although these experiments showed only partial protection by MB34 monoclonal antibody, the results however are consistent with a concept of cross-protection between $N$. meningitidis $\mathrm{B}$ and $E$. coli $\mathrm{K} 1$. The observed difference in susceptibility is probably due to the large difference in virulence between the challenge organisms. The $\mathrm{LD}_{50}$ for $E$. coli $\mathrm{K} 1$ was found to be less than 5 c.f.u. mouse, i.e. 100 times more virulent than strain $N$. meningitidis CN7619 (group B). To verify the specificity MB34 was also tested in mice subsequently challenged with $32 \mathrm{LD}_{50}$ of a group $\mathrm{C}$ strain (CN7038) without any positive effect. Conversely, mice challenged with group B (CN7619) strain were not protected either by normal mouse serum, or unrelated monoclonal antibodies. These results are not shown. 


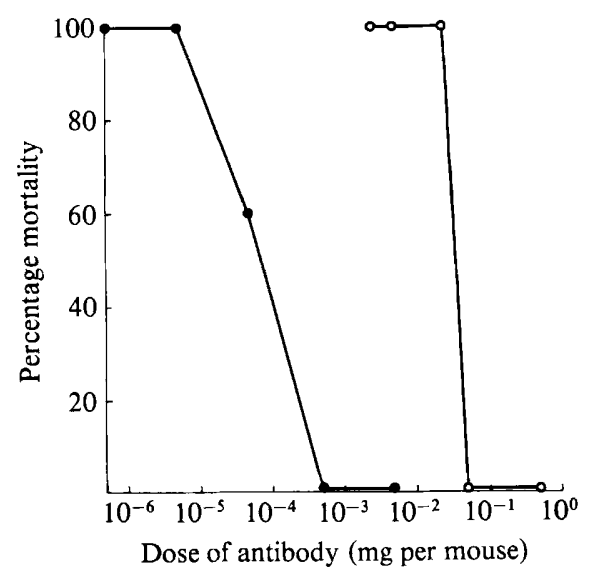

Fig. 2. Protective capacity of monoclonal antibodies MB32 (O) and MB34 (O). $\mathrm{CBAT}^{6}$ female mice received dilutions of a stock solution of antibody $\left(2.2 \mathrm{mg}\right.$ antibody $\left.\mathrm{ml}^{-1}\right)$ intraperitoneally $1 \mathrm{~h}$ prior to challenge with $32 \mathrm{LD}_{50}$ of $N$. meningitidis $\mathrm{CN} 7619$, group B, in combination with $10 \mathrm{mg}$ iron dextran.

Table 2. Passive protection with MB34 monoclonal antibody given $4 \mathrm{~h}$ after challenge with $N$. meningitidis

$\mathrm{CBA} / \mathrm{T}^{6} \mathrm{~T}^{6}$ female mice (five per group) were injected with $32 \mathrm{LD}_{50}$ of strain $\mathrm{CN} 7619$ and $10 \mathrm{mg}$ iron dextran followed $4 \mathrm{~h}$ later by $0.2 \mathrm{ml}$ of antibody MB34. All injections were given intraperitoneally.

\section{Amount of MB34 injected ( $\mu \mathrm{g}$ per mouse)}

$$
\begin{aligned}
& 8 \cdot 8 \\
& 4 \cdot 4 \\
& 2 \cdot 2 \\
& 1 \cdot 1 \\
& 0
\end{aligned}
$$

\begin{tabular}{|c|c|c|}
\hline \multicolumn{3}{|c|}{ Mortality at: } \\
\hline $24 \mathrm{~h}$ & $48 \mathrm{~h}$ & $72 \mathrm{~h}$ \\
\hline 0 & 0 & $0^{*}$ \\
\hline 0 & 0 & $1^{*}$ \\
\hline 0 & 0 & $1^{*}$ \\
\hline 0 & 0 & $0^{*}$ \\
\hline 2 & 5 & 5 \\
\hline
\end{tabular}

* A $\chi^{2}$ test indicated that these values are significantly different from the control, with a value of $P<0 \cdot 01$.

Table 3. Effect of MB34 monoclonal antibody given $24 \mathrm{~h}$ before challenge with $N$. meningitidis

Conditions were the same as for Table 2, except that antibody MB34 was given $24 \mathrm{~h}$ before challenge with $32 \mathrm{LD}_{50} N$. meningitidis $\mathrm{CN} 7619$.

$\begin{array}{cccc}\begin{array}{c}\text { Amount of MB34 injected } \\ (\mu \mathrm{g} \text { per mouse) }\end{array} & \overbrace{24 \mathrm{~h}}^{\text {Mortality at: }} \\ 4.5 & 0 & 1 & 72 \mathrm{~h} \\ 0.45 & 0 & 5 & 1^{*} \\ 0 \cdot 045 & 0 & 3 & 4 \\ 0 & 0 & 4 & 5\end{array}$

* Significantly different from the control, with $P<0.01$.

Table 4. Protective effect of MB34 monoclonal antibody on mice challenged with $E$. coli KI

$\mathrm{CBA} / \mathrm{T}^{6} \mathrm{~T}^{6}$ female mice (15 per group) received MB34 intraperitoneally $1 \mathrm{~h}$ prior to challenge with 40 c.f.u. of $E$. coli $\mathrm{K} 1$ and $10 \mathrm{mg}$ iron dextran (both injected intraperitoneally).

Amount of MB34 injected ( $\mu \mathrm{g}$ per mouse)

$\begin{array}{lc}4 \cdot 5 & 12 \\ 0 \cdot 45 & 7^{*} \\ 0 \cdot 045 & 12 \\ 0 & 15\end{array}$

* Significantly different from the control, with $P<0.01$. 


\section{DISCUSSION}

The data present demonstrate the protective role of anti-group $\mathrm{B}$ meningococcal antibodies in mice. Some protection was obtained against $E$. coli $\mathrm{K} 1$; this is in agreement with previous observations that passive antibody can protect rats injected with $E$. coli $\mathrm{K} 1$ (Bortolussi \& Ferrieri, 1980) and confirms the specificity of the effect. The difference in protective capacity obtained with monoclonal antibody MB34 when tested with $N$. meningitidis $\mathrm{CN} 7619$ and $E$. coli $\mathrm{K} 1$ (CN6158) probably reflects the 100-fold difference in virulence observed for these strains, although other explanations are possible. MB34 is an IgM, complement-fixing antibody, and the complement dependence of protection against $N$. meningitidis (Nicholson \& Lepow, 1979) and E. coli $\mathrm{K} 1$ (Stevens et al., 1978) has been reported although it has not established unequivocally whether protection is due to bactericidal activity, to C3b-dependent opsonization or both. A relationship between protection against $E$. coli $\mathrm{K} 1$ and complement activity restricted to the classical pathway has been established (Stevens et al., 1980), but this is not necessarily the case for $N$. meningitidis.

Poor protection was observed with MB32 and complement fixation could not be demonstrated with this antibody. These findings tend to strengthen the association between complement fixation and protection. However, other factors could play a role: MB34 seems to have greater avidity for antigen than MB32 and rough estimates with the crude systems available to us would indicate approximately a 10 -fold difference in avidity between the two. Moreover, Mandrell \& Zollinger (1982), have recently published a comparative study for avidity of human and mouse antibodies specific for meningococcal $\mathrm{B}$ and $\mathrm{C}$ antigens, and found the former to be low. It is difficult to interpret data of this kind; but it might very well be the case that MB32 did not protect for two reasons: lack of complement fixation and poor avidity.

The protective capacity of IgM monoclonal antibodies specific for Streptococcus pneumoniae type 3 (Briles et al., 1981 a) and phosphorylcholine (Briles et al., 1981 b) has been established. According to these reports, as little as $20 \mu \mathrm{g}$ antibody (or possibly less) confers complete protection on CD mice. This compares well with the protection obtained with MB34 for $N$. meningitidis, as seen in Fig. 2. Here, complete protection was obtained with $1 \mu \mathrm{g}$ antibody, and a minimally protective dose can be put as low as $10 \mathrm{ng}$ antibody per mouse. In terms of antibody molecules these data correspond to about $0.5 \times 10^{6}$ molecules per bacterium, a very large quantity by comparison with IgM anti-Salmonella adelaida antibody where only eight molecules per bacterium promoted phagocytosis in vivo (Rowley \& Turner, 1966). However in these experiments the bacteria and antibodies were premixed before injection, thus maximizing the efficiency of the antibody.

Although a simpler murine model based on mortality has been published (Huet \& Suire, 1981), N. meningitidis is considered as poorly pathogenic for laboratory animals (Goldschneider et al., 1969) unless it is treated with mucin or administered along with iron (Holbein et al., 1979; Jones et al., 1980) which has been described as essential for bacterial multiplication in vivo (Holbein, 1980). The fact that iron-promoted infection by $N$. meningitidis can be controlled with anti-B antibodies suggests that such a model could be used to study not only passive protection but also active immunity in vaccinated mice and can be considered as a useful complement to the mouse bacteraemia model as described by Craven \& Frasch (1979).

The central issue in this communication is the fact that IgM antibodies specific for polysaccharide $B$ are sufficient to confer protection. A similar protective role of murine $\mathrm{IgG}_{3}$ specific for phosphorylcholine and anti-SIII pneumococcal polysaccharide has been reported recently (Briles et al., 1981a). We now intend to clarify whether B-monoclonal antibodies belonging to other classes and subclasses are also effective.

The authors are indebted to Drs J. Ivanyi, M. T. Scott and N. Rapson for reviewing the manuscript, and to Mrs J. Esdaile for her assistance during the late stages of the experimental work.

\section{REFERENCES}

AdLAM, C. \& ScotT, M. T. (1973). Lympho-reticular stimulatory properties of Corynebacterium parvum and related bacteria. Journal of Medical Microbiology 6, 261-273.
Bhattacharjee, A. K., Jennings, H. J., Kenny, C. P., Martin, A. \& SMith, I. C. P. (1975). Structural determination of the sialic acid polysaccharide antigens of Neisseria meningitidis serogroups B and C 
with C13 nuclear magnetic resonance. Journal of Biological Chemistry 250, 1926-1932.

Briles, D. E., Clafin, J. L., Schroer, K.\& Forman, C. $(1981 a)$. Mouse $\mathrm{IgG}_{3}$ antibodies are highly protective against infection with Streptococcus pneumoniae. Nature, London 294, 88-90.

Briles, D. E., Nahm, M., Schroer, K., Davie, J., Baker, P., Kearney, J. \& Barletta, R. (1981 b). Antiphosphocholine antibodies found in normal mouse serum are protective against intravenous infection with type 3 Streptococcus pneumoniae. Journal of Experimental Medicine 153, 694-705.

Bortolussi, R. \& Ferrieri, P. (1980). Protection against Escherichia coli $\mathrm{K} 1$. Infection in newborn rats by antibody to $\mathrm{K} 1$ capsular polysaccharide antigen. Infection and Immunity 28, 111-117.

Calver, G. A., Kenny, C. P. \& Lavergne, G. (1976). Iron as a replacement for mucin in the establishment of meningococcal infection in mice. Canadian Journal of Microbiology 22, 832-838.

Coates, A. R. M., Hewitt, J., Allen, B. W., Ivanyi, J. \& Mitchison, D. A. (1981). Antigenic diversity of Mycobacterium tuberculosis and Mycobacterium bovis detected by means of monoclonal antibodies. Lancet 2, 167-169.

CounTs, G. W. \& TuRCK, M. (1977). Screening for cross-reactive capsular polysaccharide $\mathbf{K}$ antigens of Escherichia coli using antiserum agar. Journal of Clinical Microbiology 5, 490-491.

Craven, D. E. \& Frasch, C. E. (1979). Protection against group $\mathrm{B}$ meningococcal disease: evaluation of serotype 2 protein vaccines in a mouse bacteremia model. Infection and Immunity 26, 110-117.

Frasch, C. E., Parkes, L., McNelis, R. M. \& Gotschlich, E. C. (1976). Protection against group B meningococcal disease. I. Comparison of groupspecific and type-specific protection in the chick embryo model. Journal of Experimental Medicine 144, 319-329.

GoldsChNeider, I., Gotschlich, E. C. \& ARTENSTEIN, M. S. (1969). Human immunity to meningococcus. I. The role of humoral antibodies. Journal of Experimental Medicine 129, 1307-1326.

Gotschlich, E. C., Rey, M., Etienne, J., Sanborn, W. R., Triau, R. \& Cvietanovic, B. (1972). The immunological responses observed in field studies in Africa with group A meningococcal vaccines. Progress in Immunobiological Standardization 5, 485491.

Gotschlich, E. C., Austrian, R., Cvjetanovic, B. \& Robbins, J. B. (1978). Prospects for prevention of bacterial meningitis with polysaccharide vaccines. Bulletin of the World Health Organization 56, 509518.

Holbein, B. E. (1980). Iron-controlled infection with Neisseria meningitidis in mice. Infection and Immunity 29, 886-891.

Holbein, B. E., Jericho, K. W. \& Likes, G. C. (1979). Neisseria meningitidis infection in mice: influence of iron, variations in virulence among strains and pathology. Infection and Immunity 24, 545-551.

HUET, M. \& SUIRE, A. (1981). Un modèle animal pour l'activité des vaccins polyosidiques meningococciques. Journal of Biological Standardization 9, $67-74$.

Jones, R. L., Peterson, C. M., Grady, R. W. \& Cerami, A. (1980). Low molecular weight ironbinding factor from mammalian tissue that potentiates bacterial growth. Journal of Experimental Medicine 151, 418-428.

Kasper, D. L., Winkelhake, J. L., Brandt, B. L. \& ARTENSTEIN, M. S. (1973a). Antigenic specificity of bactericidal antibodies in antisera to Neisseria meningitidis. Journal of Infectious Diseases 127, 378387.

KaSPER, D. L., WinkelhaKe, J. L., ZollingeR, W. D., BRANDT, B. L. \& ARTENSTEIN, M. S. (1973b). Immunochemical similarity between polysaccharide antigens of $E$. coli $\mathrm{O} 7: \mathrm{K} 1(\mathrm{~L}): \mathrm{NM}$ and group B Neisseria meningitidis. Journal of Immunology 110, 262-268.

Kohler, G. \& Milstein, C. (1975). Continuous cultures of fused cells secreting antibody of predefined specificity. Nature, London 256, 495-497.

Lifely, M. R., GilberT, A. S. \& Moreno, C. (1981). Sialic acid polysaccharide antigens of Neisseria meningitidis and Escherichia coli: esterification between adjacent residues. Carbohydrate Research 94, 193-203.

Mandrell, R. E. \& Zollinger, W. D. (1982). Measurement of antibodies to meningococcal group B polysaccharides: low avidity and equilibrium binding constants. Journal of Immunology 129, 2172 2178.

Nicholson, A. \& LePow, I. H. (1979). Host defense against Neisseria meningitidis requires a complementdependent bactericidal activity. Science 205, 298299.

Rowley, D. \& TURner, K. (1966). Number of molecules of antibody required to promote phagocytosis of one bacterium. Nature, London 210, 496.

Stevens, P., Shena, N-Y., Huane, D. W. \& Young, L. S. (1978). Restricted complement activation by Escherichia coli with the K-1 capsular serotype: a possible role in pathogenicity. Journal of Immunology 121, 2174-2180.

Stevens, P., Chu, C. L. \& Young, L. S. (1980). K-1 antigen content and the presence of an additional sialic acid-containing antigen among bacteremic K-1 Escherichia coli: correlation with susceptibility to opsonophagocytosis. Infection and Immunity 29, 1055-1061.

Wyle, F. A., Artenstein, M. S., Brandt, B. L., Tramont, E. C., Kasper, D. L., Altieri, P. L., Berman, S. L. \& Lowenthal, J. P. (1972). Immunologic response of man to group B meningococcal polysaccharide vaccines. Journal of Infectious Disease 126, 514-522. 